\title{
RAMÓN, Sociedad Limitada. Consumo y creación en la estética de Ramón Gómez de la Serna
}

\section{RAMÓN Society Ltd. Consumption and Creation in the Aesthetics of Ramón Gómez de la Serna}

\author{
Ricardo Fernández Romero \\ University of St. Andrews
}

\section{RESUMEN}

A partir del análisis de la naturaleza de la mercancía, su circulación y su consumo, nuestra investigación propone entender la creación de imágenes literarias de Ramón Gómez de la Serna como el descubrimiento de la naturaleza estética (o el posible aprovechamiento estético) de los mecanismos sociales y económicos del fetichismo de la mercancía descrito por Karl Marx. Las dos ediciones de El rastro (1914 y 1931) serán el terreno para esta exploración. Las diferencias entre ambas ediciones, junto al estudio de otros textos ramonianos, mostrará la evolución del autor en cuanto a las implicaciones estéticas de diferentes formas de consumo en el contexto del desarrollo del capitalismo en el primer tercio del siglo XX en España.

Palabras Clave: Ramón Gómez de la Serna, consumo, mercancía, fetichismo.

\begin{abstract}
This article will study the literary practices and aesthetic conceptions of Ramón Gómez de la Serna in the context of the processes of consumption and production of the capitalist system. The Marxist analysis of the fetishism of the commodity will guide us in the exploration of Ramón's relations with the objects in El Rastro (1914 and 1931). The differences in the two editions of this work, and a consideration of other texts by this author, will allow us to trace the evolution of Ramón's aesthetics along his changing attitudes to capitalist development in Spain during the first third of the $20^{\text {th }}$ century.
\end{abstract}

Key words: Ramón Gómez de la Serna, consumption, commodity, fetishism.

Las cosas y Ramón. Se trata de un binomio o una pareja ineludible al enfrentarse a buena parte, si no toda, de la ingente, casi inabarcable obra de Ramón Gómez de la Serna: el artista y la materia de su trabajo. Esta interacción debe traducirse con más detalle en una doble dinámica: por un lado el 
desmenuzamiento descriptivo de la realidad en sus más nimios y variados aspectos y por otro la sede y la marca de un estilo literario, un nombre propio, para esa catalogación creativa y transmutadora de prácticamente cualquier realidad. Siendo esto innegable, el ya viejo lugar común de hablar, así, del «amor de Ramón por las cosas» deja sin aclarar, sin embargo, qué se entiende por «cosas» o de qué modo trabaja Ramón sobre ellas mediante su peculiar sistema productivo. En estas páginas propondremos entender ese sistema como realización de los mecanismos estéticos presentes en una cierta interpretación de las relaciones económicas que gobiernan la realidad del sistema capitalista que encontró el escritor. Naturalmente, muchos son los contemporáneos de Ramón que acusan el impacto social, cultural, del desarrollo del capitalismo, su capacidad radicalmente transformadora. Como Ramón, muchos optimistas abrazarán la continua proliferación de lo «nuevo», en forma de mercancías y de nuevas relaciones sociales entre los hombres y éstas, y convertirán unas y otras en tema de sus obras de arte. Pero pocos como Ramón llegaron entonces a hacer de esas transformaciones no sólo el tema, sino el sistema de su propio proceso creativo. Algunos perspicaces observadores identificaron muy tempranamente la profunda dimensión «comercial» (entiéndase en todo el sentido de la expresión) del arte de Ramón, especialmente evidente en sus libros más fragmentarios. De entre ellos, qué mejor que traer aquí de ejemplo (pero también como apertura de los temas de nuestra discusión) este comentario a propósito de Muestrario debido a Carmen de Burgos, Colombine, su compañera de tantos años:

Muestrario es [...] como su título indica, un verdadero muestrario, y si hubiera corredores del género de Gómez de la Serna, sería éste el libro que llevarían los comisionistas $[\ldots]$

Ante la diversidad de este catálogo o muestrario de hallazgos y de visiones se sospecha lo que puede dar de un modo más completo y extenso la fábrica de Gómez de la Serna, puesta a prueba a través del tiempo (1999: 362).

El libro-cosa y sobre todo el libro-mercancía, con estructura y funcionamiento de tal; el libro producto de un proceso «industrial» de creación; el libro-catálogo de mercancías literarias, con función de tales mercancías, etc., son algunos de los aspectos que humorísticamente señala Colombine y que aquí intentaremos explorar. Así, proponemos, en la estela de esta ramoniana estetización de la economía y de una posible lectura económica de esa estética, abundar en los trabajos de Juli Higfill y José-Miguel Marinas sobre las relaciones entre la cultura del consumo y la greguería, para profundizar en la intuición ramoniana de la dimensión semiótica de la economía política tal como la describió, bastantes años después, Jean Baudrillard en sus primeros estudios de la década de 1970. Como clave de este proyecto nos introduciremos en el laberinto ramoniano a partir de la organización económico-espacial de su relación con las «cosas», es decir, del motor artístico de 
dos tiempos que impulsa la fábrica de Gómez de la Serna: consumidor de mercancías en el espacio económico-geográfico de la ciudad, principalmente, y productor artístico de mercancías estéticas y de libros-mercancía, catálogos de «cosas» para los que habrá de buscar Ramón su espacio de consumo en la ciudad. Este acercamiento a los espacios del ramonismo pretende observar la correspondencia o contigüidad de las formas de circulación de las mercancías y la circulación de las greguerías, metáforas (tomadas ellas mismas como mecanismos de puesta en relación de entidades, conceptos, realidades diversas) y otras invenciones recogidas en esos libros «sin género» que Ioana Zlotescu en su edición de las Obras completas de Ramón ha agrupado como «ramonismo»: El Rastro, Muestrario, Libro nuevo, Disparates, Variaciones, El alba, Pombo, La Sagrada Cripta de Pombo, Ramonismo, Caprichos, Gollerías, Los muertos, las muertas y otras fantasmagorías, Trampantojos, a los que deben añadirse las diversas ediciones de Greguerías, y los libros que nunca hizo pero donde hubiera recogido sus artículos de viajes, sus columnas en la prensa, como «Horario», «Ángulos de Madrid», etc. Sólo por falta de espacio no nos ocuparemos de todos, ni tampoco de las novelas.

Desde su primera obra comercial ${ }^{1}$ (El Rastro, 1914), hasta Ismos (1931), la etapa central de la carrera de Ramón (si aceptamos dividir su obra aproximadamente en las tres fases que indicara en su clásico estudio Rodolfo Cardona ${ }^{2}$ ), va desde la irrupción del escritor marginal a su aclimatación y posterior éxito (más espectacular que comercial) en el espacio de la sociedad burguesa de su tiempo. Aunque si recordamos aquí Ismos como una de sus últimas grandes obras de su mejor periodo es por lo que tiene de recuento de fin de etapa, y por coincidir en ese mismo año con la reedición de El Rastro, tan diferente la de 1931 de la primera edición, como veremos. El recorrido de Ramón es el del consumidor en tránsito entre espacios comerciales y prácticas de consumo diferentes y distantes en el tiempo, que aun así conviven, en una superposición muy del gusto de Ramón, podríamos suponer. Ese es el tránsito que estudiaremos aquí: el que hace el post-adolescente que desde los márgenes de las pautas de consumo y producción burguesas va a integrarse en ellas plenamente conforme avance la década de los años 20 para perseguir ese éxito de mercado ${ }^{3}$

${ }^{1}$ Rafael Cansinos Assens considera El Rastro como la: «primera condescendencia con el público» de Ramón (Gómez de la Serna, 1996: 263).

${ }^{2}$ Así las enumera Cardona: «Adolescence (1904-1915), his middle period, when he is at the peak of his popularity (1916-1935), and his late period, starting around 1942». El autor añade una cauta advertencia a la que nos adherimos: «Of course, this tentative division is highly arbitrary, since it would be impossible to draw a definite line with which to make a clear-cut separation between these hypothetical periods of his literature» (1957: 147).

${ }^{3}$ Ramón, incansable propagandista de sí mismo, incluye en Libro nuevo (1920), como es sabido, numerosos artículos acerca de la recepción de su obra. Entre ellos, este testimonio de Antonio de Hoyos da fe de la persecución del éxito por parte de Gómez de la Serna: 
del que hablaba Colombine. A este respecto, según José-Carlos Mainer, el año de 1923 podría fecharse como el de la cumbre de ese proceso (Mainer, 2000: 11).

Una primera precisión nos parece fundamental, como se desprende del texto, de todos sus textos: el modo en que las «cosas» en Ramón no aparecen de forma aislada, sino en su calidad de mercancías, o mejor, como escribe Arjun Appadurai, posicionadas socialmente como mercancías: «I propose that the commodity situation in the social life of any «thing» be defined as the situation in which its exchangeability (past, present or future) for some other thing is its socially relevant feature» (1986:13). Nuestra investigación pretende mostrar, precisamente, cómo en la base de la greguería, sus procedimientos metafóricos y metonímicos consisten precisamente en recorrer las ilimitadas posibilidades del intercambio económico a todo rendimiento de las mercancías. Resulta por tanto consustancial la conexión revelada por Juli Highfill (2008: 18-20) de la greguería y el lenguaje publicitario de la época. En cualquier caso, el flaneur que es Ramón (en su vida y en tantos de sus escritos) es, también, un turista en su propia ciudad; y como tal se acerca al espacio urbano: como su consumidor-cronista. Ramón envidia al puro turista en un lugar desconocido, como ya escribió en 1916 en el epílogo a uno de los libros de viajes de Carmen de Burgos: «iEnvidia del extranjero en nuestra patria y de ese monóculo del extranjero de unas diatrías (sic) perspicaces y descubridoras!» (Gómez de la Serna, 1916: 453).

Como es sabido, Ramón usará un monóculo sin cristal para «observar» más de cerca la realidad. Esta pasión escópica y descifradora que atribuye al turista le convierte, de hecho, en lo que es en definitiva todo turista, según Jonathan Culler: «an agent of semiotics», dedicado a entender «objects and practices as cultural signs» (1988: 155). En ello transforma Ramón la realidad, pero la labor del turista, como la de Ramón, va más allá de la «lectura» de la realidad. Si como escribe John Ury, «[The tourist gaze] is constructed through signs and tourism involves the collection of such signs» (1995: 133), entonces el turista participa en una relación económica con la realidad, como consumidor, coleccionista y, en el caso de Ramón, difusor de la colección adquirida. No hará falta insistir en la pasión coleccionista de Ramón, expresada en la creación de sus despachos (McCulloch y Ávila, 2002), en el contenido y estructura de muchos de sus libros misceláneos, etc. A partir de aquí debemos preguntarnos en qué consiste ese coleccionismo productivo de Ramón, si se puede decir así, cuál es la relación con las «cosas» que se deriva a partir de esa actividad semiótica, cuyo punto de partida es inseparable de las estruc-

«Aparentemente el autor de Morbideces vive en su torre de marfil; en la realidad, no; ha ido al público contra su voluntad; se ha hecho comprensible y comprensivo, pese a sus esfuerzos por ser lejano y hermético, en una lejanía y un hermetismo irónicos y desdeñosos» (Gómez de la Serna, 1999c: 321). 
turas económicas de acceso y consumo de las cosas-mercancías y si, en consecuencia, es posible, al menos en líneas generales, trazar la evolución de esta práctica artístico-económica ramoniana.

\section{El CONSUMO Y LAS MERCANCÍAS EN EL RASTRO: EL MOMENTO DE DESHACER}

Proponemos empezar nuestro recorrido por la ciudad-mundo literario de Ramón en busca de las respuestas a nuestras preguntas siguiendo el camino indicado por el propio escritor. El viejo Madrid del Rastro será la primera estación, por tanto; es decir, el lugar emblemático del periodo inicial de su carrera en el que Ramón va a encontrar la voz que luego cultivará hasta el exceso (y con la que en la madurez querrá enmudecer el recuerdo de la voz anarquizante de sus textos de adolescencia más radicales). El hallazgo se escenifica en el desconcertante Libro mudo (1911), al final de ese peripatético recorrido por la ciudad y sus afueras, cuando sobreviene el encuentro con el Rastro. En seguida se transforma ese espacio de mercado en una especie de laboratorio estético-filosófico, singularmente al margen de la ciudad y sus valores, donde se descubre la especial relación social de las mercancías entre sí y con el posible comprador:

Ramón, todo allí es una cuestión de casualidad y de arbitrariedad... [...] Nada mantiene su tenacidad en querer ser lo que es; se rinde y encuentra bien su rendición, que es una victoria al fin y una fuga que detenía la testarudez (Gómez de la Serna, 1996a: 734).

La perplejidad ante el enigma de las cosas en el Rastro lleva al descubrimiento de que el intercambio de mercancías en economías o mercados sujetos a la lógica del bazar, como escribe Arjun Appadurai, exige una serie de complejos conocimientos: «It is tempting to conclude that such complex and culturally organised information mazes are a special feature of the bazaar-style economies, and are absent in nonmarket, simple economies, as well as in advanced industrial ones» (1986: 21). La falta de estandarización, por tanto, abre el paso a la pura especulación, tanto la de los compradores enfrascados en averiguar el valor de uso y negociar su valor de cambio, como la de nuestro joven observador que, en un nivel estético, halla pie para intuir la liberación sin límites de las posibilidades del ser-cosa. El principio de identidad salta por los aires, dejando el campo abierto a la libre acción de la metáfora que podrá comparar todo con todo, romper ligaduras de sentido basadas en la lógica de la utilidad o cualquier otra (y de paso cumplir las famosas «siete palabras» programáticas de Ramón: «oh, si llega la imposibilidad de deshacer»). A este descubrimiento, sin embargo, desemboca Ramón gracias a la subyacente «fe en el mundo greguerístico» de que hablara Cesar Nicolás (citado en Highfill, 2008: 22) y que según Eloy Navarro Domínguez corresponde a la 
concepción monista del universo del adolescente Ramón en la que se incluirían ingredientes diversos (tomados de Epicuro, Haeckel, etc.) y que darían por resultado, precisamente, «la visión de un universo divisible al infinito en fragmentos» (2003: 271). Sin embargo, creemos que es en el mercado y a través de la lógica económica del Rastro cómo ese monismo se revela en la práctica y en ese momento inaugural de certificación de las posibilidades estéticas de la realidad del mercado. Concurrimos por tanto con Highfill cuando escribe:

La fe en la interconectada unidad de un mundo atomizado y que admite la desenfrenada intercambiabilidad de sus componentes muy bien puede seguir el ejemplo de una economía basada en la simple fe en la moneda, una economía caracterizada por una circulación de mercancías sin fin [...] Interpreta [Ramón] literalmente los principios de equivalencia y de conmensurabilidad que gobiernan el mundo simbólico - tanto económica como lingüísticamente- (2008: 22).

El siguiente paso lo da en «Tristán. Propaganda al libro de Tapices», incluido en Tapices (1912), cuando el despacho privado de Tristán/Ramón (el primero de unos cuantos) se convierte en una réplica del laboratorio estético del Rastro. Por último, llegamos a la exploración sistemática del Rastro que se dará en el libro homónimo, de 1914. Sin duda El Rastro ofrece una estructura más clara en comparación a los anteriores, incluso una cierta ordenación irónicamente simbólica aprovechando la configuración geográfica de ese mercado callejero de la ciudad: el «descenso» del narrador al Rastro y el posterior «ascenso», espiritualmente purificado, de vuelta a la ciudad. Pero también es, de nuevo, un lugar de experimentación estética: «Pero el Rastro es sobre todo, más que un lugar de cosas, un lugar de imágenes y de asociaciones de ideas $[\ldots] \gg(78)$.

¿Pero qué lleva a Ramón a este interés por el Rastro cuando en realidad el capitalismo ya hacía tiempo que ofrecía el espectáculo de la mercancía en el mismo Madrid, en galerías y escaparates, cuando Ramón había vivido en París entre 1909 y 1911? ¿Por qué a este admirador de lo nuevo le interesan «los trastos viejos e inservibles»? A este respecto, como ejercicio contextualizador, cabría recordar que ese curioso escritor del siglo XIX, Antonio Flores, acaso un precursor de las indagaciones ramonianas (aparece, por cierto, citado en $P$ ombo ${ }^{4}$ ), ya se le había adelantado en 1863, observador y flaneur de Madrid, cuando describe así la animación fantasmagórica de las cosas en su calidad de mercancías:

\footnotetext{
${ }^{4}$ Escribe Ramón: «—Aquí venía D. Antonio Flores- nos ha dicho Azorín. (¡Oh, qué grato es que D. Antonio, aquel hombre que se adelantó a la ironía y la observación de ahora, se sentase en estos divanes y mirase al mismo techo en el que parece que nos encontramos con su mirada, así como con otras miradas interesantes y perplejas!)»(Gómez de la Serna, 1999a: 55).
} 
De escaparate en escaparate, como quien camina por un inmenso túnel de cristal, pasaremos una y otra calle, siempre con el billete [de banco] en la mano y siempre haciendo saltar en los andenes las piedras preciosas, los vasos de china, las telas de seda, y cuantos objetos de lujo ha podido inventar la coquetería de la industria, para engañar y seducir al oro. A ese Adán de los metales constantemente halagado por la publicidad para que peque en el paraíso de la moda (Flores, 1863: 10-11).

Dejando de lado el carácter tan moderno de esta observación benjaminiana avant la lettre, debemos indagar qué enfrenta para Ramón estas calles de Antonio Flores, que parecen ya las del Madrid nuevo de los años veinte y treinta, a su querido Rastro. En primer lugar, podríamos adivinar una postura irónica del joven que juzga a su civilización no por el esplendor de sus escaparates sino por sus desechos, como si pretendiera señalar no sólo la infatigable capacidad creadora del sistema capitalista, sino también, inseparable del mismo, su voracidad destructora. La violencia del proceso se metaforiza en un naufragio cuyos vestigios llegan al Rastro (Gómez de la Serna, 1998: 74). Se trata de un escenario de muerte, de ruinas, cuyo carácter de tales deriva de su ser ya inservibles; es decir carentes, prácticamente, de valor de uso y de valor de cambio. La metáfora de las ruinas, sin embargo, le merece a Ramón ciertas precisiones desmitificadoras de índole estética y moral: no son cosas de anticuario o de museo, «no son tampoco ruinas históricas y trascendentales estas cosas del Rastro [...]» (Gómez de la Serna, 1998: 77).

En ese desdramatizar se descubre una continuidad de sus radicalidades antiburguesas adolescentes. Así, las «cosas» no resultan aptas para el consumo de una burguesía ávida de reconocimiento a través de la apropiación individual de un pasado, o de la apropiación colectiva de la historia institucionalizada. Todo lo contrario: lo subversivo de los objetos del Rastro es su resistencia al discurso burgués que identifica Ramón (en una perspicaz ecuación semiótico-sociológico-económica) con sus prácticas de consumo:

Resultando incomparables esas tiendas turbias y funestas, con la airosa mundanidad, con el diogeniano espíritu de los puestos al aire libre. En esas prenderías metidas en las casas, hay una linfática burguesía que no sienta bien al libertarismo, a la bohemia, que necesitan los objetos huidos. Los apresa, los encona, los conserva, los coloca en escaparates con cristal, les hace guardar un orden y una compostura forzada sobre las cómodas o dentro de vitrinas abominables, los ahoga en cuartos de aspecto doméstico, faltos de aire, de libertad en que descomponerse y hallar su glorificación (Gómez de la Serna, 1998: 92-93).

Tal discurso «convencional» impone una univocidad de sentido, una «compostura» de clase social, podría decirse, y una distancia (tras el cristal de los escaparates que tanto admirará Ramón, sin embargo, pasados unos cuantos años). A salvo de ese lugar fijo en el discurso, en el Rastro, al no ser casi nada (al no significar; es decir, carecer de valor para el consumo burgués) las cosas adquieren la capacidad de deshacerse, disgregarse, para cargarse (de la 
mano de las operaciones estéticas de Ramón) de un nuevo significado: ser espejo deformador, irónico, subversivo, de ideas y discursos establecidos, de curso legal. En otras palabras: «ni intentan ninguna demasía imperialista, y su sentido es breve, porque abominan de la retórica», (Gómez de la Serna, 1998: 78) de la retórica burguesa, por supuesto.

Esta operación critica de Ramón es posible porque parte de un aspecto ya apuntado: la «muerte» de las cosas y la intervención estética de Ramón. Cuando Ramón escribe (en la segunda edición de El Rastro, en 1931) «A través de los años lo que queda más verdadero es el Rastro en seria función de muerte de las cosas» (Gómez de la Serna, 1998: 712), se refiere a la «muerte» económica de la cosa, la cesación de su valor de uso y de su valor de cambio, o la confusión ante cuál sea el valor de uso y cuál el de cambio del objeto «inútil». En esa situación el consumidor y flaneur que es Ramón se encuentra ante un enigma. La base de ese enigma de la cosa en el Rastro es en realidad su paradójica situación económica expresada en la metáfora de la ruina. Lo que el objeto ofrece son los vestigios, el recuerdo de un valor de cambio ya no efectivo. Ese valor de cambio que ocupa todo el sentido de la mercancía al abandonarla deja ahí ante nosotros y ante Ramón la fantasmal presencia de una ausencia, por decirlo con palabras de Giorgio Agamben (Estancias, 1995). El enigma de la cosa introduce entonces una interesante dimensión espaciotemporal en el objeto que aparece en el Rastro, porque en el fondo el objeto no ha muerto, más bien se nos muestra como en un estado agónico o intermedio, fantasmal, alucinatorio por tanto (Bush, 2005: 99-100). En definitiva, aún se espera venderlo, como bien viera el periodista V. Gutiérrez de Miguel, en su artículo «El Rastro madrileño a la hora de la siesta. Un paseo llevando como guía a Ramón Gómez de la Serna»: «porque nada de lo que viene al Rastro muere definitivamente... Lo más, sufre un aletargamiento indefinido; pero todo espera que alguna vez le llegue la hora de volver a vivir» (1929: 3 ). Frente a esa naturaleza equívoca, actualizar el valor de cambio, comprar el objeto absurdo, implica en el fondo una curiosa operación temporal: en el Rastro conviven pasado y presente, y acaso el futuro de ese «volver a vivir». Esa multiplicidad de tiempos señala un fenómeno bien moderno que Ramón capta y aprovecha estéticamente en una suerte de arqueología del presente. Así, ante la huella del pasado visible en un mueble Ramón pueda escribir en este añadido de la edición de 1931 de El Rastro: «Un mueble, un objeto, no son ni un mueble ni un objeto, sino ideas, teorías de un tiempo, una concepción diferente del hogar y del amor» (Gómez de la Serna, 1998: 764).

Del aprovechamiento del pasado para las metáforas nace lo nuevo: de ahí que no sea contradictorio el amor del escritor de vanguardia por antonomasia por las cosas «viejas». Ramón, a través de la transmutación metafórica de las cosas que describe hace vivir de nuevo las cosas (las consume de nuevo). Encontramos entonces, casi como lógica conclusión, la idea de la crónica del Rastro como una escritura «futurista» (al ramoniano modo): «Había que modifi- 
car de algún modo esa literatura de las crónicas, [...] literaturas inspiradas solamente en el pasado, como único leitmotiv del Rastro, sin ver en él toda la cantidad infinita de porvenir que le asiste, que en él se aduna» (Gómez de la Serna, 1998: 82). Pero conviene retomar esa idea de la «arqueología» del presente, porque Ramón no solo constata en esta forma artística de consumir las cosas del Rastro (sobre la que habremos de volver) los efectos de la nueva dimensión temporal que impone la moda en las prácticas de consumo de la sociedad de su tiempo, sino que la convierte en parte de su proceso estético. Permítasenos usar como ilustración esta anécdota, acaso no fiel, pero tan sintomática, recogida en el diario $\mathrm{Luz}$, en el que tanto colaborara nuestro escritor. Un anónimo redactor transcribe estas palabras de nuestro autor: «Vengo [al Rastro] —dice Ramón con toda seriedad - a que me enseñe usted todas las nuevas antigüedades que tenga» («Vilanos en el aire», 1934: 3). En efecto, el consumo de los «trastos» del Rastro se rige para Ramón por el sistema de la moda como del mismo modo su literatura se atiene a la producción de lo nuevo. Ramón descubre por su cuenta tanto las implicaciones estéticas como las posibilidades para la práctica artística de una vorágine de consumo que, como muestra José-Miguel Marinas, el sociólogo Georg Simmel había identificado desde inicios de siglo como propia de la moda. Esta, según el mismo Simmel, «por su juego entre la tendencia a una expansión total y el aniquilamiento de su propio sentido que esta expansión acarrea, adquiere el atractivo peculiar de los límites y los extremos, el atractivo de un comienzo y un fin simultáneos, de la novedad y, al mismo tiempo, de la caducidad» (Marinas, 2002: 130). De ahí proceden tanto un agudo sentido de la historicidad del presente, subrayado por cómo los objetos de «antes de ayer», recién desechados, podríamos decir, conviven con otros más antiguos, amenazando con engullir el presente y devolverlo ya como pasado, terminado; como, por otro lado, paradójicamente, la gozosa capacidad liberadora de mezclar tiempos que elimine el yugo de sujetarse a la historia. Pero este «ser y no ser» (Marinas, 2002: 131) a un tiempo de las cosas en el vértigo de la moda tiene además de su lectura celebratoria una más «honda» o angustiante, existencialista, que corresponde a esa siempre presente y justamente señalada preocupación por la muerte de Ramón ${ }^{5}$. Una preocupación en línea con sus gustos barrocos y, sobre todo, transformada a partir de los años treinta en la búsqueda de su entronque con un ascetismo cada vez más acendrado (como demuestran las dos ediciones, en 1935 y 1945, de Los muertos, las muertas y otras fantasmagorías), pero cuyas raíces creemos que se encuentran también,

\footnotetext{
${ }^{5}$ José-Carlos Mainer había detectado tempranamente este aspecto en los objetos desechados del Rastro como razón para el interés de Ramón en ellos: «La vida que se confiere a los objetos depende ahora de los números de la economía: por eso lo cursi — la inutilidad de lo arrumbado por la moda- atrae al escritor y éste nos transmite el confuso grito de lo que se revela contra su muerte» (1972: 28).
} 
por paradójico que parezca, en esta asunción materialista de esa temporalidad/ atemporalidad del consumo. Veamos con algún detalle esa lectura existencialista del consumo en el Ramón anterior a la Guerra Civil.

Ya sea por lectura directa de Marx (algunos de cuyos textos sí conocía y citaba en su adolescencia), ya sea por sus propias dotes de observador, cuando Ramón en Tapices escribía «somos nuestras cosas, como las cosas son sus cosas» (Gómez de la Serna, 1996b: 915) se acerca a ese famoso fragmento de $E l$ Capital en el que el filósofo alemán establece la existencia de «a definite social relation between men, that assumes, in their eyes, the fantastic form of a relation between things» (Marx, 1976: 165). Si Ramón parece abrazar lo que Marx llama el fetichismo ${ }^{6}$ de la mercancía, y la reificación de la vida humana, también acepta que la caducidad de nuestra naturaleza, incluso la consistencia de esa naturaleza, corresponde, como cualquier otra mercancía, al imperio de la moda $^{7}$. Esto explica el curioso final de la protagonista de la novela corta encajada (¿acaso como otro objeto más?) en la segunda edición de El Rastro, «La abandonada del Rastro», pues, efectivamente, Renée «en el puesto cerrado, se deshacía en sus componentes» (Gómez de la Serna, 1998: 733). La extensión de esta lógica reificadora conduce a esos inquietantes momentos de la obra ramoniana, por cierto, en el que aparecen con insistencia, como en la propia vida del autor, los seres-objeto, los «entes plásticos», como los llama Ana Ávila (2001), medio vivos y medio muertos (como el «ser y no ser» de las cosas), verbigracia, su famosa muñeca de cera; la «mujer de cera», escribe Ramón.

Pero si volvemos al escenario de El Rastro, de nuevo la existencia humana entre las cosas, sometida a la categoría de mercancía, o su dimensión suspendida entre vida y muerte, entre pasado y presente, ese estado de latencia y de indefinición, de «ser y no ser», de ser uno mismo cosa, proporciona la posibilidad de una superación de lo humano para hallar un consuelo filosófico, místico ${ }^{8}$. No por casualidad tal logro se halla al final de este extraño mercado, como conclusión al viaje «espiritual» que es también el paseo por el Rastro:

\footnotetext{
${ }^{6}$ Para un entendimiento psicológico del fetichismo en Ramón véase Cabañas Alamán (2001).

${ }^{7}$ Como las modas, las personas, convertidas en imágenes, aparecen y desaparecen, literalmente y figuradamente también, con la misma velocidad, según leemos en Pombo: «Por esos espejos vastísimos de los cafés, con diez horizontes visibles, se ve a la humanidad que pasa un momento frente a ellos, como una humanidad efímera que no nos acabamos de imaginar bien. Pasan y se mueren. Indudablemente es algo así. La señora, el obrero, la jovencita, fallecen al pasar. Y después de todo, la verdad es que es así. Después de todo, esa es la verdad» (Gómez de la Serna, 1999a: 35).

${ }^{8}$ Así lo entiende Michael Ugarte: «The excess and waste are precisely what gives the flea market something of a mystical quality. The Rastro, or «the things of the Rastro», evoke a variety of thoughts and sensations: the return to origins, the smell of decay, death, rebirth, isolation, connection, vastness» (Ugarte, 1996: 109-110).
} 
Aquí se siente la ausencia verdadera, la ausencia completa de la ciudad; nos quedamos como sin padre ni madre - como si no los hubiéramos tenido nunca—, sin honor, sin historia, sin propiedad, sin destino [...], dentro de un vasto ensimismamiento, vasto porque no es hermético, ya que durante él carecemos de límite que separe nuestro interior de nuestro exterior (Gómez de la Serna, 1998: 247).

Ramón parece contarnos que ha logrado colocarse más allá de los valores de la burguesía, de la civilización urbana. Irónicamente, ha analizado en El Rastro las implicaciones estéticas y filosóficas de la mercancía, las ha llevado hasta sus últimas consecuencias. En otras palabras, es como si Ramón hubiera adaptado la famosa frase de admiración y asombro de Marx ante el desarrollo y funcionamiento del capitalismo, «todo lo sólido se disuelve en el aire» ${ }^{9}$ y la hubiera hecho el eje estético de su práctica artística: «oh, si llega la imposibilidad de deshacer» ${ }^{10}$.

\section{LECCIONES DE ECONOMÍA POÉTICA: EL MOMENTO DE LA CREACIÓN}

Si en esta etapa adolescente y tardo-adolescente, hasta 1914, Ramón insiste en el «deshacer», no es menos cierto que en el mismo Rastro sienta las bases del proceso de creación sobre el que se basará su prolífica actividad greguerística en los años sucesivos ¿En qué consiste esa práctica? Hemos adelantado algunos aspectos ya en la caracterización de lo que encuentra en el Rastro y lo que le interesa de esas mercancías. Volvamos y ampliemos estos aspectos. Como indicábamos arriba, el papel de Ramón en el Rastro es el de un flaneur o un turista, preferiríamos nosotros, cuya actividad de mirador es en realidad, la de un consumidor de cosas, guiado por su pasión escópica. Esas cosas, en realidad, se le aparecen en calidad de mercancías, es decir, a partir de su valor de cambio. Como resume Marinas «El flaneur es el virtuoso de esta identificación. Lleva en su paseo el concepto mismo de venalidad» (2002: 135). En ese reconocimiento del valor de cambio el paseante sienta las bases para una curiosa dualidad de la mercancía que Ramón aprovechará hasta sus

\footnotetext{
${ }^{9}$ Karl Marx escribe: «Constant revolutionizing of production, uninterrupted disturbance of all social conditions, everlasting uncertainty and agitation distinguish the bourgeois epoch from all earlier ones... All that is solid melts into air, all that is holy is profaned, and man is at last compelled to face with sober senses, his real conditions of life, and his relations with his kind» (Communist Manifesto, 161-162).

${ }^{10}$ Soldevila-Durante ha señalado el conocimiento por parte del adolescente Ramón de ciertos textos de Marx, entre ellos El manifiesto comunista. A propósito de la evolución política del joven escritor apunta: «Desde 1910 Ramón abandona sus ideales revolucionarios (incluido su conocimiento de diversos textos de Marx) y se acerca a un programa de abstención y aislamiento evasivo» (Soldevila-Durante, 1988: 27). Desde nuestro punto de vista, esto no conlleva que olvide Ramón lo aprendido en Marx, de modo que lo utiliza a su manera, con intenciones ajenas a cualquier planteamiento revolucionario, pero conservando las posibilidades estéticas que estamos describiendo.
} 
últimas consecuencias. Karl Marx explica los primeros pasos del proceso de desdoblamiento de la mercancía así:

The product becomes a commodity, i.e. a mere moment of exchange. The commodity is transformed into exchange value. In order to equate it with itself as an exchange value, it is exchanged for a symbol which represents it as exchange value as such. As such a symbolized exchange value, it can then in turn be exchanged in definite relations for every other commodity (1973: 145).

De este modo nos acostumbramos, como el paseante, a la mercancía como otra cosa que ella misma, como símbolo además de objeto:

Because the product becomes a commodity, and commodity becomes an exchange value, it obtains, at first only in the head, a double existence. This doubling on the idea proceeds (and must proceed) to the point where commodity appears double in real exchange: as a natural product on one side, as exchange value on the other. I. e. the commodity's exchange value obtains a material existence separate from the commodity (Marx, 1973: 145).

Esa existencia material del valor de cambio es el dinero. Marx continúa: «In the form of money all properties of the commodity as exchange value appear as an object distinct from it, as a form of social existence separated from the natural existence of the commodity» (1973: 145). Separado el valor de cambio, convertido en algo abstracto, sin embargo presente en la mercancía, es posible manipular ese valor de cambio, trabajar sobre él como el terreno de juego para el juego metafórico, pues a fin de cuentas, como hemos indicado ya, el valor de cambio permite a las mercancías ser comparadas unas con otras, sin tener en cuenta cuál es su naturaleza como objetos. Para ayudar a ello, por otro lado, la variación en los precios hace factible (como en los procesos especulativos) la libre flotación del valor de cambio. Marx lo explica por extenso así:

The same contradiction between the particular nature of the commodity as product and its general nature as exchange value, which created the necessity of positing it doubly, as this particular commodity on one side and as money on the other - this contradiction between the commodity's particular natural qualities and its general social qualities contains from the beginning the possibility that these two separated forms in which the commodity exists are not convertible into one another. The exchangeability of the commodity exists as a thing beside it, as money, as something different from the commodity, something no longer directly identical with it. As soon as money has become an external thing alongside the commodity, the exchangeability of the commodity for money becomes bound up with external conditions which may or may not be present; it is abandoned to the mercy of external conditions (1973: 147).

Esas condiciones externas (como la oferta y la demanda) indican el momento en que la mercancía puesta en circulación se abre a los avatares del consumo que puede dictar así el valor de cambio (además, o por encima, in- 
cluso, de las condiciones de producción que se incluyen en principio en el valor de cambio como cantidad de trabajo abstracta invertida en la producción de la mercancía). No se trata, conviene aclarar, que Ramón se fije en el dinero que tal o cual mercancía valga, sino en esa fascinante abstracción que es el valor (de cambio) que, en el juego de la moda, de lo novedoso, puede concederse caprichosamente a ciertos objetos y no a otros, nunca en función de lo que «sean» sino a partir de las misteriosas reglas del mercado. En realidad, necesitamos tener en cuenta otro elemento más para entender cómo Ramón trabaja con las posibilidades del valor de cambio. Marx nos lo ofrece en un famosísimo pasaje de El Capital, en el que recorre precisamente, casi en paralelo a las operaciones mentales de Ramón, el mismo camino del objeto (en este caso una mesa) a la imagen delirante:

The form of wood, for instance, is altered, by making a table out of it. Yet, for all that, the table continues to be that common, every-day thing, wood. But, as soon as it steps forth as a commodity, it is changed into something transcendent. It not only stands with its feet on the ground, but, in relation to all other commodities, it stands on its head, and evolves out of its wooden brain grotesque ideas, far more wonderful than «table-turning» ever was (Marx, 1976: 163-164).

En efecto, el fragmento corresponde al capítulo I de El Capital, a su sección dedicada al estudio del fetichismo de la mercancía. No se trata aquí de hacer de Marx el antecesor en el cultivo de la greguería de Ramón, pero no nos parece caprichoso llamar la atención sobre la animación de esa mesa marxiana y en lo cerca que está esa imagen, considerada literariamente, de las greguerías ramonianas. Creemos que se trata no tanto de una influencia, aunque no se pueda descartar, dado el acreditado conocimiento de Marx por parte de Ramón, como de una feliz coincidencia entre el análisis del filósofo y la intuición del escritor a partir de su común enfrentamiento con la realidad de la mercancía y del sistema capitalista.

En todo caso, Marx entiende de forma negativa esta imagen, como una veladura en la mente del consumidor de las relaciones de producción entre las mercancías y de estas con los hombres, de modo que alienadas estas de ellos, las relaciones sociales y económicas se reifican, o adquieren «vida propia». Ramón, sin embargo, abraza esa fantasmagoría. Dicho de otra manera, una vez olvidadas las relaciones sociales y obliterada la economía política sobre la que llama la atención Marx, se puede entonces elucubrar y fantasear sobre la independencia de la mercancía de toda atadura social ${ }^{11}$. Puede entonces especularse sobre su falta de origen (en relación a la fuerza de trabajo abstracta invertida) y se puede jugar con la libre flotación de valor de cambio al que

\footnotetext{
${ }^{11}$ A diferencia pues de lo que afirma Antonio del Rey Briones, si Ramón aprecia la cosas por sus «valores evocativos y poéticos», no es porque ignore su «condición de mercancía sujetas a leyes económicas» (1992: 81), sino porque es de esas condiciones de donde brotan esos valores estéticos que el artista aprovecha y explota hasta sus últimas consecuencias.
} 
se ofrece la mercancía. Al mismo tiempo, entonces, Ramón sustituye las relaciones laborales de la mercancía que observa por otro tipo de relación: el trabajo de producción del poeta, del creador, de Ramón. En este trabajo el creador aprovecha el exceso de sentido de la mercancía, su fantasmagórico flotar independiente del objeto en sí: cuando el precio de la mercancía puede ser completamente independiente de su valor de cambio entendido como cantidad de trabajo necesario para producir la mercancía, entonces la mercancía puede ser cualquier cosa, compararse con cualquier valor de cambio de cualquier mercancía; puede, en consecuencia, cristalizar en cualquier metáfora. De este modo, Ramón va más allá de Marx en la misma dirección, curiosamente, de la exploración del capitalismo llevada a cabo por Jean Baudrillard a partir de su análisis de la sociedad de consumo. Compárense los procesos estéticos ramonianos sobre el fetichismo de la mercancía con el análisis de las consecuencias de ese fetichismo según Baudrillard:

Thus the fetishization of the commodity is the fetishization of a product emptied of its concrete substance of labour and subjected to another type of labour, a labour of signification, that is, of coded abstraction (the production of differences and of sign values). It is an active, collective process of production and reproduction of a code, a system, invested with all the diverted, unbound desire separated out of the process of real labour and transferred onto precisely that which denies the process of real labour. Thus fetishism is actually attached to the sign object, the object eviscerated from its substance and history, and reduced to the state of marking a difference, epitomizing a whole system of differences (1981: 93).

En otras palabras, Ramón descubre y aplica en el campo de la estética y la creación literaria una visión semántica de las características de la circulación y el intercambio de las mercancías que el pensador francés empieza a desarrollar varias décadas más tarde. A este respecto Baudrillard escribe: «It is because the structure of the sign is at the very heart of the commodity form that the commodity can take on, immediately, the effect of signification - not epiphenomenally, in excess of itself, as "message" or connotation - but because its very form establishes it as a total medium, as a system of communication administering all social exchange» (1981: 146). El filósofo establece una homología entre la lógica de la significación (significante/significado) y la lógica de la economía política (valor de uso/valor de cambio), en la que la primacía, en paralelo a Ramón, se concede al juego de los significantes, separado de las ataduras metafísicas con la «realidad». Así lo formula Baudrillard:

In reality, this moral and metaphysical privilege of contents (UV [valor de uso]) and Sd-Rft [significado-referente] only masks the decisive privilege of the form (EV [valor de cambio] and Sr [significante]). These two terms are respectively the «Reason», the structural principle of the entire system, of which the former terms are only the detour. It is the rational abstraction of the system of exchange value and of the play of the signifiers which commands the whole (1981: 156).

A ese juego del valor de cambio/significante y sus múltiples combinaciones se entrega Ramón. En el caso del escritor madrileño, sin embargo, la or- 
ganización en un código de diferencias no obedece a la lógica colectiva que señala Baudrillard, sino que es, acaso como parodia, como imitación, como espejo deformante y caprichoso, la que, sin abandonar la misma lógica (la lógica de la moda, sin más sentido que su propia sistematicidad), reside en la imaginación de un único individuo. El resultado es un código paralelo y no necesariamente contradictorio con aquel que según Baudrillard ordena el sentido del consumo de las mercancías, es decir, su sentido.

Ramón, al mismo tiempo, lleva a cabo un acto de consumo (evaluación de su valor de cambio) y uno de creación de una nueva realidad (una nueva mercancía, el objeto-imagen/imagen-objeto resultado del consumo-elucubración poética). El trabajo de Ramón re-crea entonces el mismo proceso de consumo que sucede en el capitalismo como lo entenderá más tarde Baudrillard:

This is the process of consumption considered as a system of sign exchange value: not consumption as traditional political economy defines it (reconversion of economic exchange value into use value, as a moment of the production cycle), but consumption considered as the conversion of economic exchange value into sign exchange value (1981: 113).

Sin embargo, nosotros sí entendemos el proceso de consumo de Ramón como una forma de producción, de consumo productivo, si se quiere, en tanto que ofrece el resultado del consumo (la conversión del valor de cambio en valor de cambio de signos, objetos-signo) como mercancías a su vez destinadas al consumo cultural, sometido a los dictámenes de la moda, de lo nuevo en literatura.

A su vez, esto ofrece la ventaja de otorgar un origen a la nueva mercancía-objeto estético: la imaginación del poeta. Se supera así la alienación de la mercancía en relación al trabajador, inherente en las formas de producción capitalista, de paso que se justifica el origen fantasmagórico del universo resultante, del universo ramoniano, naturalmente. Así, si como escribió Adorno «[la mercancía es un] bien de consumo que no debe recordar en nada cómo ha llegado a nacer» (1939: 1-2), porque el momento de la creación no puede ser reproducido (Baudrillard, 2005: 81), Ramón precisamente opera de forma contraria, revirtiendo la crisis de la memoria, de la que ha escrito Richard Terdiman (1993) como característica de la civilización capitalista ${ }^{12}$. Como corolario debemos considerar el intenso autobiografismo de la obra de Ramón, su constante exposición, hasta el punto, buscado adrede, en el que se confunden las mercancías artísticas de Ramón con su creador: «quiso ser un objeto de consumo», ha escrito acertadamente Marinas (2002: 233).

${ }^{12}$ Este mismo fenómeno a propósito de El Rastro es considerado desde una perspectiva diferente por Jean-Antoine Díaz cuando escribe sobre el poder restaurador y unitario del acto creador ramoniano de este modo: «Nous avons donc affaire à un culte de l'origine qui, dans sa volonté de dépasser le dualisme, ne peut considérer le passé que sous la forme d'un retour actuel du geste instaurateur. Ce qui fait retour, c'est donc le pouvoir de créer de l'inédit ou, si l'on veut, la vitalité ascendante» (1999: 74). 
Aplicado este proceso a los objetos del Rastro, tenemos que, a todos los efectos, Ramón lleva a cabo una re-valorización de las cosas. Como tal, esta consiste en una actualización del valor a partir del trabajo artístico invertido. Traer así la mercancía agonizante en el Rastro a la vida es traerla a la vida del mercado, con un valor de cambio actual, comprensible, como obra artística, como «concepto generalizado» entre el público (Hoyle, 1986: 286). Así se entiende la resurrección de las cosas:

En el albur que corra toda cosa desportillada, celebrará de camino el misterio de su pasión, de su palabra, de su muerte y de su resurrección. [...]

Y así entrarán y continuarán en Dios, que es solo espacio, reintegro y acomodo del todo en el todo. Por esto este libro no será nunca un libro retrospectivo (Gómez de la Serna, 1998: 82).

En efecto, el libro de Ramón se dirige hacia el futuro, el tiempo nuevo en el que la cosa antigua vuelve a circular como objeto-imagen. En este sentido, comparte algunas de las características señaladas por Baudrillard a propósito de las antigüedades aunque las parodie al mismo tiempo. Según Baudrillard, el objeto «antigüedad» significa el pasado, adquiere en ese sentido un carácter mitológico. Pero sobre todo, en cuanto a su función en el contexto del presente de su intercambio como mercancía, la antigüedad

It is that which occurs in the present as having occurred in a former time, hence that which is founded upon itself, that which is 'authentic'. The antique is always, in the strong sense of the term, a 'family portrait': the immemorilization, in the concrete form of an object, of a former being - a procedure equivalent, in the register of the imagery, to a suppression of time (Baudrillard, 2005: 79).

La naturaleza dual de la fotografía a la que alude Baudrillard en su referencia al retrato familiar, el ser y el representar un estado anterior, lo descubre Ramón en los objetos desahuciados del Rastro, lo adopta y lo aplica a sus creaciones imaginísticas como emblemas de la naturaleza especial de los desechos del capitalismo. De hecho, como creación lingüística, materia (como parte de un libro) y abstracción (memoria), sus imágenes son el vehículo perfecto para transmitir esa paradójica cualidad de ser y no ser (de haber sido) a un tiempo. En este sentido, recogiendo esta dualidad propia de la fotografía, hablamos en estas páginas de los objetos-signo de Ramón. Pero Ramón, como ya indicamos, señala la distancia de las cosas del Rastro con respecto a las antigüedades. En realidad, en su resurrección de las cosas, se aparta de un modo irónico de ese valor de la antigüedad descrito por Baudrillard. Si bien, como estas, los objetos-signo encuentran su fundamento en ellos mismos, es decir, como creaciones ramonianas, no remiten a ninguna autenticidad que no sea la del propio ingenio, o en todo caso, en un giro aparentemente autoconsciente, la disparatada y humorística imagen apunta tanto al deseo como a la necesidad de aceptar y disfrutar por ese humor de la imposibilidad de recuperar autenticidad alguna para las cosas fabricadas en masa por el capitalismo. De paso, para reforzar la carga irónica, debe recordarse, como ya men- 
cionamos, la velocidad de consumo de una sociedad que marca con el peso del pasado lo que apenas si es reciente, de modo que coloca paródicamente a la bagatela en la posición nostálgica de la antigüedad. Quedan, como escribe Baudrillard, las trazas de la creación (2005: 81). Sin embargo, en consonancia con las observaciones de Baudrillard, si recordamos el bienestar de Ramón al final de su paseo por el Rastro, una nueva explicación a esa felicidad puede añadirse: el descubrimiento y fruición de la multiplicidad temporal de los objetos del Rastro que dota a los textos de Ramón, a pesar de su carga costumbrista, de esa misma sensación de multiplicación de tiempos, de ser literatura nueva y retrospectiva a un tiempo.

Así, en resumen, de la arqueología del pasado (y del presente ya histórico) se pasa a su puesta en circulación, curiosa capacidad demiúrgica del artista, ligada a la vida de la cosa en el mercado. El arte de Ramón no pierde de vista el pasado, pero con razón y orgullo mira al futuro, pues es el arte de lo viejo hecho nuevo. Por lo mismo también un arte perecedero, como la moda de cuya naturaleza, de cuyo sistema participa. Como la moda, que Marinas ha visto prefigurada en las intuiciones nietzscheanas del eterno retorno, el de Ramón es un arte que supera la caducidad de sus objetos-signo, caducidad paralela a la de las mercancías que re-nueva al metaforizar sobre ellas, aumentando el caudal de cosas nuevas, de objetos-signo. Acaso sea esta una manera de entender tanto la grafomanía del escritor (además de responder a su deseo de ganarse bien la vida únicamente con el desempeño de su arte), como su queja habitual y patética, expresada así en «Mi autobiografía», de 1924: «Para mí, la sensación es que no he escrito aún ninguno [ningún libro], que no me he podido dedicar a su ejecución con la serenidad absoluta en que pienso producirme alguna vez» (1999b: 727). Es decir, no ha producido la obra «clásica» que habrá de quedar, sino literatura de consumo, rápidamente olvidada, como realmente sucedió en buena medida con tantas de sus obras.

A ese caudal de cosas nuevas da Ramón salida a través de una circulación constante: en sus libros-catálogo entran y salen a cada instante metáforas, greguerías y fragmentos, haciéndolos distintos en cada edición y confundiendo a su propio creador, que pierde la cuenta de los trasvases. La circulación se extiende a la deliberada confusión de espacios públicos y privados: sus despachos son Rastros como lo son sus libros-catálogo; el café de Pombo es el lugar de circulación de sus metáforas (y de sus libros, que reparte a los contertulios), como lo son las «performances» de sus «conferencias-maleta», en las que improvisa greguerías a medida que hace aparecer ante los asistentes absurdos cachivaches. La multiplicidad de la ciudad moderna y la intercambiabilidad de sus espacios y los usos de los mismos está enraizada en la forma de entender Ramón su arte como la re-novación y puesta en circulación de sus objetos-signo por todos los medios (incluida la radio, no se olvide) para el mayor número de consumidores. En otras palabras, «[la greguería es] voz del mercado, voz de las cosas en el espacio del consumo» (Marinas, 2002: 251). Coincidimos por tanto con la reciente y fundamental aportación de Laurie-Anne Laget para la cual el estudio del nacimiento del 
ramonismo y de la greguería debe situarse «dans les lois du marché et de la consommation de son époque» (Laget, 2012: 381). Queremos abundar en esta perspectiva y ampliarla aquí mediante el estudio de la circulación de ese ramonismo.

La circulación, en fin, constituye, como contenido, y al mismo tiempo, como forma del contenido de buena parte de la práctica artística de Ramón, lo que en términos de Fredric Jameson podríamos llamar el ideologema ramoniano. Contemplamos aquí la obra no como texto aislado, sino como «the smallest intellegible unit of the essentially antagonistic collective discourses of social classes» (Jameson, 1981: 76). No en vano, como veremos en el siguiente apartado, la propia consideración del libro como obra cerrada es puesta en duda por Ramón, de modo que el principio de la circulación se enfrenta dialécticamente con la hipocresía ideológica (burguesa) del orden cerrado, implícito en la celebración idealista de la Obra de arte. Entendida de esta manera la palabra ramoniana constituye «a symbolic move in an essentially polemic and strategic ideological confrontation between the classes» (Jameson, 1981: 85). Por lo tanto, la circulación como ideologema ramoniano supone una organización dialógica del discurso de clase (burgués) con decidida voluntad polémica, desde dentro del mismo, acaso contradictoria en ocasiones. Se coloca aquí Ramón en una posición excéntrica, con respecto a su clase, como diría Antonio Prieto, pero sin abandonarla ideológicamente, muy al contrario $^{13}$. Podemos así matizar la «independencia política» del escritor. De este modo, a las resistencias de una cierta burguesía (y sus aliados en otros ámbitos sociales) ante los nuevos valores sociales y culturales propiciados por la circulación incesante del sistema económico que la sustenta, Ramón opone la radicalización liberadora de los fundamentos estéticos que se pueden desprender de esa misma circulación. A la vez, como discutiremos en la siguiente sección, problematiza la naturaleza del producto artístico creado y discute dialécticamente cómo, en tanto que libro-objeto, aquél es a la vez resultado de un proceso creador y portador en sí de la caducidad propia de la mercancía. El carácter alienado del trabajo artístico, del que se mostrará muy consciente, le lleva a enfrentarse a esta dialéctica, desplazando su resolución a la celebración de un febril proceso creador interminable. Quizá aquí se halle también una explicación para su ingente productividad artística.

\section{EL LIBRO-OBJETO: EL MOMENTO DE LA CIRCULACIÓN EN EL MERCADO}

Vista en su aspecto de puesta en circulación de mercancías, o de objetossigno, las prácticas artísticas de Ramón participan de ese fenómeno urbano del

\footnotetext{
${ }^{13}$ «Ramón seguirá excéntrico y en ese su estar fuera del centro no podrá situarse en ningún eje generacional con espíritu de cuerpo normativo y por su excentricidad buscará la perturbación que es la vida de las cosas, su vida en las cosas mediante múltiples relaciones o asociaciones que le conducen lingüísticamente a la greguería» (Prieto, 2005: 189).
} 
contacto de mundos y espacios en un principio socialmente y culturalmente distantes, incluso segregados. No solo se trata de estrategias de diversión y «enclaving» (Appadurai, 1986: 56) que ponen en relación diferentes sistemas económicos (el comprador del Rastro y el consumidor elitista de arte minoritario en el caso de Ramón) e intensifican el consumo de los objetos en uno y/u otro de los sistemas hacia los que circulan las mercancías. Cuando Ramón consigue «colocar» como charlatán chamarilero lo «antiartístico» (lo vulgar, lo obsoleto, la basura) como «arte» y ser, además, aplaudido, ironiza jocosamente sobre el mundo del arte y sus productos entendidos como práctica de consumo refinado, intelectual, burgués.

En este sentido, nos parece que Ramón usa los objetos cursis en tanto que fuente de sus pasiones estéticas y también como paralelo irónico de su propio quehacer artístico. En efecto, si seguimos a Noël Valis, del mismo modo como en la sociedad industrial sucede con la expansión del consumo de lo cursi, Ramón sitúa el arte marginal en el centro, glorifica el consumo artístico de lo banal y celebra, en su necesidad de favorecer la máxima circulación posible del objeto estético, la invasión de la intimidad por objetos artísticos producidos en masa (Valis, 2002: 231-238). Tal arte manufacturado a escala industrial es el signo de la estetización de la realidad que el capitalismo extiende sobre todas las mercancías y aun, como sabemos hoy, sobre cualquier experiencia. Hacia esa estetización de la realidad entera se encamina Ramón con su «fabricación industrial» de objetos-signo ${ }^{14}$.

Dentro de esta lógica industrial, Ramón asume tanto el propio carácter de mercancía de El Rastro, como el constituir también un catálogo de mercancías. Esto le supondrá, en primer lugar, afrontar las consecuencias de su circulación en el mercado. Un problema que aparece sobre todo en el «Ex-Libris» de la edición de 1914, desdoblado en las meditaciones generales sobre lo perecedero de su libro como mercancía (del mismo modo que sucede a las cosas en su circulación), así como en la expresión de la angustia causada por la concreta inserción de su producto dentro de un mercado literario hostil a las novedades ramonianas.

En cuanto al primer aspecto, si el Rastro le sirve de inspiración, también es el destino en que el objeto, el libro como cosa, aparecerá y perecerá:

Durante muchos años he hecho largos viajes a través de él [el Rastro], intentando darle fondo, pero sin pensar nunca hacer un libro con su asunto, cuando de pronto una tarde de vuelta a la ciudad me he encontrado [énfasis del autor] ya hecho, impreso y atezado este libro, como si lo hubiese adquirido en un baratillo de libros viejos, con mi nombre en la portada y con algo del sentido, de la concepción que yo habría querido darle. (Gómez de la Serna, 1998: 80)

Como todas las mercancías, el libro, El Rastro, se da antes como producto industrial que como obra ideal, expropiada («ya hecho», como hecho por otro),

\footnotetext{
${ }^{14}$ Así se veía ya en la época, como leemos en este comentario de Jorge Manach: «Había momentos en que RAMÓN nos parecía una divertida maquinilla de hacer inversiones de imágenes triviales» (1928: 212).
} 
de modo que cualquier sentido artesanal del oficio de escritor se elimina sin sentimentalismo. La relación del autor con su propia obra se mediatiza a través del proceso industrial, se hace extraña como lo es la presencia de cualquier mercancía, pues tanto éstas como los objetos-signo que crea Ramón comparten un mismo sentido, un mismo lugar dentro de la lógica semiótico-económica del capitalismo. Ramón asume así el libro como objeto muerto o moribundo, para poner de este modo una nota de irónico distanciamiento. Sucede así, ni más ni menos, con cualquier libro encontrado en el Rastro: «Todos se vuelven contra uno, hasta los mismos que uno escribió y que ha encontrado aquí» (1998: 148).

Contempla Ramón su propia obra dentro de la vorágine de la «destrucción creadora» del capitalismo. Marx notó en su momento esa dialéctica ${ }^{15}$ y desde entonces, aunque con un sentido distinto, la destrucción creadora del capitalismo se ha convertido, a partir de Schumpeter, sobre todo, en una de sus extrañas virtudes. En la obra de Ramón ambos vectores son el motor de su propia obra: crear tanto a partir de las cosas desechadas como de la propia obra, interminablemente reciclada en las habituales transfusiones de textos de un contexto a otro de la producción ramoniana.

Creación y destrucción, o producir deshaciendo, son dos caras de la misma moneda, pero dentro de este período central de la obra de Ramón, se da un distinto énfasis a cada uno de los dos momentos, según se va consolidando su posición dentro del mercado literario. Quizás en sus inicios la voluntad de deshacer pesa más en el adolescente radical y el joven que aún debe encontrar su sitio. De ahí la insistencia con que entre 1915 y 1920 repite en varias ocasiones un conocido fragmento de su «Primera proclama de Pombo» a favor del «libro inclasificable, el libro violento, el libro ultravertebrado, el libro cambiante y explorador, el libro libre en que se insertase el libro del libro, en que las fórmulas se desenlazasen al fin» (Gómez de la Serna, 1999a: 213) ${ }^{16}$. En 1920 acude a esas mismas palabras en una entrevista a Santiago Vinardell, recogida en Libro nuevo para oponerlas a lo que el mercado le pide: «El editor quiere novelas. Y no edita más que mediocridades y reputaciones» (Gómez de la Serna, 1999c: 127). El producto comercialmente viable frente al libro inclasificable, desenlazado. Pronto encontrará la forma de superar esas tensiones y de abrazar el mercado, de modo que el «abastecimiento» del mismo le preocupará tanto como para, sin descontar otras razones, justificar sus retiros a Nápoles o escribir como «final» de su autobiografía de 1924: "Yo me habré metido en Estoril a escribir novelas» (Gómez de la Serna, 1999b: 744), las ya no tan detestadas novelas ${ }^{17}$. Acaso

15 «The violent destruction of capital not by relations external to it, but rather as a condition of its self- preservation, is the most striking form in which advice is given it to be gone and to give room to a higher state of social production» (Marx, 1973: 749-750).

${ }^{16}$ La «Primera proclama de Pombo» aparece recogida en Esos mundos (1 de marzo de 1915), en Pombo (1918) y en Libro nuevo (1920).

${ }^{17}$ En 1922, en la revista Cosmópolis, el anónimo reseñista de La viuda blanca y negra anota certeramente este cambio: «Mas he aquí que, ratificando otros signos de su transigente evolución, este pródigo y desbordante "mirador de la vida", actualmente en la cumbre de 
un buen ejemplo de esa adaptación, sin apartarnos mucho del Rastro, lo da otra anécdota que no nos resistimos a citar, nuevamente entresacada de las páginas de Luz. El redactor anónimo de la sección «Luz pregunta» inquiere: «¿Qué puesto le gustaría tener?» A lo que Ramón, aprovechando el doble sentido responde humorísticamente (pero muy en serio, nos atreveríamos a decir):

Un puesto en el Rastro, un puesto de metáforas inesperadas, un regato de cosas absurdas y variarlas de sitio todos los días, y mezclar lo viejo y lo nuevo en esa última y depurada instancia. Acabo de publicar la guía más completa del Rastro, con su plano correspondiente, y cada vez me siento más el chamarilero pobre que vive entre imágenes queridas e invendibles («Luz pregunta...», 1932: 16).

Ramón vendedor de metáforas, de imágenes, en el propio Rastro, sí, pero también como publicista incansable de sí mismo, no se resiste a citar la reciente segunda edición de El Rastro de 1931, de venta en librerías. El chamarilero pobre no desprecia el éxito de público. Volvamos, sin embargo, a la primera edición, porque en ella se registra cómo esa transición o adaptación al mercado no se da sin pagar el precio de angustias y tensiones que se reflejan en la propia factura de la obra, con consecuencias para el estilo y la estructura del libro-catálogo ramoniano. Dichas tensiones corresponden a la paradoja o la imposibilidad del proyecto artístico de Ramón tal como lo describiera Nigel Dennis:

On the one hand, [Ramón] was side-tracked by the pressing commitments of each passing day and, on the other, he was distracted by the asombro he felt when picking over the fragments at the wayside and by the gracia of the means that occurred to him of transfiguring them artistically. He seems, in retrospect, to have undertaken a task that, despite his extraordinary facility, self-discipline and stamina, he could never complete: to create a literary reality that incorporated everything he encountered in the outside world (1988: 20).

La interminable tarea de la que habla Dennis se manifiesta, en definitiva, en la dificultad de Ramón para «cerrar»sus libros. Así en el «Ex-Libris» de la edición de El Rastro de 1914 leemos: «Oh tener que terminar un libro, tener que darlo por terminado, perderlo para siempre [...] ¿Qué nuevas cosas llegarán al Rastro mañana?» (Gómez de la Serna, 1998: 776). Consecuentemente, Ramón hincha por un buen número de páginas este afuera del libro-catálogo; pues cerrar el libro, darle forma completa y acabada es entregarlo al destino de ser cosa: mercancía con el sello de la muerte encima.

Fiel a su materialismo, el libro no es la obra, es un objeto, y como tal lo mira y sopesa como otra cosa más. ¿Cuál sería la manera de abrir material-

su madurez y en la plenitud de su producción, ya por "exigencias industriales" de este mismo desarrollo, o por el afán de mostrar una nueva faceta de su espíritu poliédrico, facilitando su traslado a cauces ortodoxos y de mayor difusión pública, llega a la novela» («Índice de lecturas», 1922: 167). 
mente el libro, de des-hacerlo? Acaso una escritura perpetua que literalmente añadiera espacio, letra impresa, en un imposible seguir des-haciendo fuera de los límites del libro, de los géneros, acaso:

¿Cómo vencer este punto muerto, que es la guarda final del blanco? ¿Cómo vencer este punto muerto, que es el Fin del libro? No veo más solución a esta pregunta interminable que seguir revelando lo que significa este punto muerto (Gómez de la Serna, 1998: 782).

La alternativa existe, por supuesto: no publicar, seguir escribiendo para sí, pero ya está Ramón entregado a su aún inconfortable relación con el mercado: no le queda más remedio que aceptar poner punto y final, que para Ramón no es sino el «ver» al fin su texto «fabricado», hecho cosa por las máquinas de los talleres de impresión:

La máquina corre como un destino intorcible, insubsanable, que no puede perder tiempo, duro con nosotros, apresurado, impaciente, inexorable, sin tregua ni plazo de gracia, arrastrándonos lejos, en un galope desenfrenado, dejándonos de pronto detrás, caídos, sobrecogidos, inútiles.

No pensamos siquiera, temerosos de que de pronto se nos vaya a ocurrir algo inexorable que querer intercalar en el texto cuando ya no se puede. Nos embriagaremos estúpidamente en el espectáculo y al fin nos resolveremos a marcharnos para no verlo (Gómez de la Serna, 1998: 797).

Ramón no puede resistir consignar su estupefacción ante el proceso de alienación de su propia obra. Incluso podríamos detectar en esa descripción de la inexorable violencia de la máquina, su energía, su brutalidad, el dolor de esa desposesión: la experiencia cotidiana, en realidad, de cualquier obrero en relación al producto de su trabajo. El trauma llega a tal punto que la alienación se convierte en una efectiva y literal desposesión: no recuerda lo escrito. Le queda, precisamente, la contemplación del «espectáculo» del proceso industrial. Pero aquí parece intuir Ramón por una vez un lado oscuro, olvidada toda querencia maquinista de, por ejemplo, los manifiestos futuristas a los que él mismo, como es bien sabido, diera inmediata cabida en Prometeo desde la década de los años diez.

No queda remedio. Así que una vez hecho, el libro, su propio libro, ya puede ser contemplado, inspeccionado no aún en el Rastro, sino en la librería. Ramón observa el recorrido de su obra, fuera del viejo Madrid del Rastro (antes de que vuelva a él como libro de segunda mano, podemos presumir):

¡Oh la promiscuidad de las librerías! [...] Se ve la silenciosa, la discreta, la gregaria actitud del libro — con sus cantoneras blancas, idiotizadas, con su lomo hipócrita-, todo en él laminado, y nos sorprendemos porque todo lo que en él pusimos fue alfarería, voluntad plástica, obra de carne, de palpitación, espacio, vastedad de tiempo, tránsito por las calles, minutos más que letras, trato con mujeres, asueto tanto como trabajo, y no hay ya nada de esto en el aún recién acabado. ¿Estaremos engañados queriendo hacer un libro de espacio y tiempo y libertad [...]? (Gómez de la Serna, 1998: 779-780). 
El libro aparece en un contexto sexualizado, como suele ser en Ramón en tantas ocasiones el acto de la compra, del consumo del objeto (sobre todo cuando la relación de poder se invierte, y el comprador es sometido por la mercancía, que se hace feminidad amenazante). En este sentido se enfatiza la capacidad de seducción de la mercancía, esa hipocresía del engaño (supuestamente «femenino»). Hasta tal punto que, de nuevo, el libro alienado parece traicionar el credo estético de su autor. Aunque también podría argüirse que de este modo se separa Ramón oportunamente (¿hipócritamente?) de su propia participación en el tinglado literario, culpando al libro. Y sin embargo, movimiento contradictorio y muy ramoniano, no se olvida de alentar y desear un público al que él también intenta seducir y halagar: «El hombre bueno, el hombre que nos comprenda, el hombre que nos importa, nos arrancará todas las espinas y verá todo lo que hay bajo nuestro martirio» (Gómez de la Serna, 1998: 782).

Continúa Ramón la observación del recorrido del libro. Una vez llegados los ejemplares que le corresponden a su casa podrá examinarlos, manteniendo esa misma distancia (y estupefacción ante su «cosa de fábrica»):

Después vendrán los ejemplares del libro en montones de mampostería. Y los miraremos uno a uno. Y los sopesaremos, llenándonos de la idea de su pesadez como de dulce peso. Miraremos su lomo tan bien planchado, tan duro, tan pulido. Nos asombraremos un poco viendo la precisión de cosa de fábrica que tiene el libro. Comprobaremos abriéndole por un lado y por otro las distancias entre unas cosas y otras. «Eso está al lado de un capítulo conmovedor, por eso se salvará y se hará perdonar». «Ahí está esa palabra que es un farol, la única luz, pero bastante de todas esas páginas que vienen después». Y cuando después de haberlo abierto por todas las dobleces por las que es legible algo del texto del libro sin cortar lo distanciaremos de nosotros y buscaremos la anchura alrededor (Gómez de la Serna, 1998: 789).

Pero acaso ya en la intimidad del hogar las páginas no le acusan del mismo modo y no debe defenderse del hecho de haber creado una mercancía para venderla. Al mismo tiempo, aprovecha que aún no ha cortado los pliegos, y no puede leerlo por entero: la dificultad material del «mecanismo» del libro para permitir su lectura se convierte en una ventaja. Encuentra la forma de consumirlo a su modo «gregueresco»: en la lectura al azar desactiva su ser mercancía (objeto terminado, cerrado) a partir de la recombinación de los hallazgos literarios en el libro contenidos. El libro se recombina, se deshace, como si reprodujera en este someterlo a su mirada el mismo mecanismo con el que contempló las cosas del Rastro. ¿Mantiene así frente al mercado la ilusión de una pureza, de una falta de connivencia, devolviendo el libro al ciclo del deshacer para rehacer? Es posible, pero en todo caso, a la luz de lo anterior, nos resulta sintomática la supresión de las ansiedades, escrúpulos o angustias de este «Ex-libris» de 1914, que desaparece en la segunda edición de 1931. No ha lugar en ese momento. Una ilustración de ese claro reposicionamiento del Ramón de los años veinte y treinta nos la da una breve narración de 1926: «El hombre de la galería», a la que nos acercaremos ahora, siquiera en unas pocas líneas. 
Aunque ambientada en la ciudad de Nápoles, el protagonista de este cuento es un asiduo de una vieja galería comercial. La galería, como el Rastro, es el lugar de la muerte de los objetos, donde queda sin sentido la definición de la mercancía (el intercambio, la circulación): las mercancías llevan «precios antiguos». Como Ramón en el Rastro, don Giovanni, el protagonista de la narración, es cronista y paseante de la galería, «sin gasto ninguno» (Gómez de la Serna, 1999d: 508). Como Ramón, consume imágenes de los objetos, incluso la suya propia multiplicada en los escaparates. Pero a diferencia de Ramón, ha gastado los objetos (sin renovarlos, como sí logra la actividad greguerizante de Ramón) y a cambio pretende inmovilizarse en ese viejo espacio de las mercancías, a salvo de la circulación en la ciudad-metrópolis. De ese modo, el escaparate del comercio que no sirve para vender objetos se transforma en un siniestro museo: «Toda la galería servía para garantizarle una vida de objeto de museo» (Gómez de la Serna, 1999d: 509). El trágico destino del personaje, sorprendente y humorístico a partes iguales, se explica enseguida si pensamos que la lámpara que le cae encima «con premeditación» y lo asesina al final de este relato no hace sino confirmar su deseo más o menos inconsciente de asimilarse a la mercancía «museizada», de querer ser cosa inmóvil, es decir, muerta. No existe refugio contra el cambio y la circulación (de personas y mercancías), sino es en la negación de lo que la vida moderna es, con las consecuencias que ello implica.

Aunque el Ramón maduro, ya en posesión de su voz característica, nunca olvide el Rastro, y su pasión por las cosas se mantenga, incluida una actualización de su práctica artística con la adición de ciertas ideas psicoanalíticas en su acercamiento a las mercancías (véase el ensayo «Las cosas y el ello»), su asentamiento en el mercado cultural de un Madrid que intenta ser cosmopolita le lleva a cambiar su relación con el viejo Madrid como fuente de su inspiración. Nunca lo abandona (ahí está su libro Toda la historia de la Puerta del Sol, publicado en 1920); pero estéticamente, su experiencia de la ciudad como centro de su práctica artística (no hablamos de los temas, sino de las formas de consumo/creación que hemos descrito) ya no se circunscribe a las afueras de la circulación de la mercancía, sino a su centro en las grandes avenidas.

\section{BIBLIOGRAFÍA CITADA}

«Índice de lecturas. La viuda blanca y negra» (1922), Cosmópolis. 42, p. 167-169.

«Luz pregunta... a Ramón Gómez de la Serna» (1932), Luz. 98, p. 16.

«Vilanos en el aire» (1934), Luz. 340, p. 3.

Adorno, Theodor (1939). «Fragmente über Wagner», Zeitschrift für Sozialforschung. VIII, 1-2, p. 17.

Agamben, Giorgio (1995). Estancias. Valencia: Pre-Textos.

Appadurai, Arjun (1986). «The social life of things», en Commodities in cultural perspective. Arjun Appadurai (ed.). New York: Cambridge University Press, pp. 9-35. 
Ávila, Ana (2001). «El «ente plástico»: Gómez de la Serna-Gutiérrez Solana (A propósito del maniquí)», Anuario del Departamento de Historia y Teoría del Arte (Universidad Autónoma de Madrid). XIII, pp. 143-182.

Baudrillard, Jean (1981). For a critique of the political economy of the sign. New York: Telos Press. Baudrillard, Jean (2005). The system of objects. London: Verso.

Burgos, Carmen de (Colombine) (1999). «Ramón Gómez de la Serna», en Ramón Gómez de la Serna, El libro mudo. Obras completas. V. Ramonismo III. Ioana Zlotescu (ed.). Barcelona: Círculo de Lectores-Galaxia Gutenberg, pp. 361-363.

Bush, Andrew (2005). «Thresholds of Visibility at the Borders of Madrid: Benjamin, Gómez de la Serna, Mesonero», en Susan Larson y Eva Woods (eds.), Visualizing Spanish Modernity. Oxford: Berg, pp. 94-111.

Cabañas Alamán, Rafael (2001). Fetichismo y perversión en la novela de Ramón Gómez de la Serna. Madrid: Laberinto.

Cardona, Rodolfo (1957). Ramon. A study of Gómez de la Serna and his works. New York: Eliseo Torres and Sons.

Culler, Jonathan (1988). «The Semiotics of Tourism», en Framing the Sign. Criticism and Its Institutions. Norman: University of Oklahoma Press, pp. 153-167.

Dennis, Nigel (1988). «Introduction. Ramón at the Centenary: The Parts of the Whole», en Studies on Ramón Gómez de la Serna. Nigel Dennis (ed.). Ottawa: Dovehouse Editions Canada, pp. 7-22.

Díaz, Jean-Antoine (1999). «La phénoménologie du Rastro par Ramón: une esthétique de l'occasion, une culture du fragment», en Ramón Gómez de la Serna. Études réunies par Évelyne Martín-Hernández. Clermont-Ferrand: Université Blaise-Pascal, pp. 61-76.

Fernández Utrera, María Soledad (2001). Visiones de estereoscopio. Paradigma de hibridación en el arte y la narrativa de la vanguardia española. Chapel Hill: North Carolina Studies in the Romance Languages and Literatures.

Flores, Antonio (1863). «Cuadro cuarenta. Los escaparates», en Ayer, hoy y mañana, o la fe, el vapor y la electricidad. Cuadros sociales de 1800, 1850 y 1899, dibujados a la pluma. Parte segunda. Hoy, o la sociedad del vapor en 1850. Madrid: Imprenta del Establecimiento de Mellado, pp. 7-23.

Gómez de la Serna, Ramón (1916). «Epílogo», en Carmen de Burgos (Colombine). Peregrinaciones. Suiza. Dinamarca, Suecia, Noruega, Alemania, Inglaterra, Portugal. Madrid: Imprenta de «Alrededor del Mundo», pp. 429-458.

Gómez de la Serna, Ramón (1996a). El Libro Mudo. Obras Completas I. «Prometeo» I. Escritos de juventud (1905-1913). Ioana Zlotescu (ed.). Barcelona: Círculo de Lectores, Galaxia Gutenberg, pp. 537-768.

Gómez de la Serna, Ramón (1996b). Tapices. Obras Completas I. «Prometeo» I. Escritos de juventud (1905-1913). Ioana Zlotescu (ed.). Barcelona: Círculo de Lectores, Galaxia Gutenberg, pp. 769-939.

Gómez de la Serna, Ramón (1998). El Rastro. Obras Completas III. Ramonismo I. Ioana Zlotescu (ed.). Barcelona: Círculo de Lectores, Galaxia Gutenberg, pp. 73-254 y 701-197.

Gómez de la Serna, Ramón (1999a). Pombo. Madrid: Visor Libros.

Gómez de la Serna, Ramón (1999b). «Mi autobiografía», en Ramón Gómez de la Serna, La sagrada cripta de Pombo. Madrid: Visor Libros, pp. 640-746.

Gómez de la Serna, Ramón (1999c). Libro nuevo. Obras completas V. Ramonismo III. Libro nuevo. Disparates. Variaciones. El alba (1920-1923). Ioana Zlotescu (ed.). Barcelona: Círculo de Lectores-Galaxia Gutenberg, pp. 46-438.

Gómez de la Serna, Ramón (1999d). «El hombre de la galería», en Obras completas XI Novelismo III. Novelas cortas y cuentos para niños (1921-1932). Ioana Zlotescu (ed.). Barcelona: Círculo de Lectores-Galaxia Gutenberg, pp. 497-509. 
Gutiérrez de Miguel, V (1929). «El Rastro madrileño a la hora de la siesta. Un paseo llevando como guía a Ramón Gómez de la Serna», La Voz. 2698, p. 3.

Highfill, Juli (2008). «Comercio metafórico: Las novísimas greguerías y su circunstancia», Boletín Ramón. 17, pp. 15-30.

Hoyle, Alan (1986). «El problema de la greguería», en Sebastian Neumeister (ed.), Actas del IX Congreso de la Asociación Internacional de Hispanistas. Berlín: Ibero-Amerikanisches Institut, Preußischer Kulturbesitz, Freie Universität Berlin, Institut für Romanische Philologie, pp. 283-292. [Frankfurt am Main: Vervuert, 1989]

Hoyos, Antonio de (1999). «Ramón Gómez de la Serna», en Ramón Gómez de la Serna, Libro nuevo. Obras completas V. Ramonismo III. Libro nuevo. Disparates. Variaciones. El alba (1920-1923). Ioana Zlotescu (ed.). Barcelona: Círculo de Lectores-Galaxia Gutenberg, pp. 321-322.

Jameson, Fredric (1981). The Political Unconscious. Narrative as a Socially Symbolic Act. Cambridge: Cambridge University Press.

Laget, Laurie-Anne (2012). La fabrique de l'écrivain: les premières Greguerías de Ramón Gómez de la Serna, 1910-1923. Madrid: Casa de Velázquez.

Mainer, José-Carlos (1972). «Prólogo», en Ramón Gómez de la Serna, El incongruente. Barcelona: Picazo.

Mainer, José-Carlos (2000). «Nueve años de novelismo (1928-1937)», en Ramón Gómez de la Serna, Obras completas XII. Novelismo IV. El caballero del hongo gris y otras novelas (1928-1937). Ioana Zlotescu (ed.). Barcelona: Círculo de Lectores-Galaxia Gutenberg, pp. 11-49.

Manach, Jorge (1928). «Márgenes al Goya de Ramón», Revista de Avance. 25, pp. 210-214.

Marinas Herreras, José-Miguel (2002). La fábula del bazar: orígenes de la cultura del consumo. Madrid: La Balsa de la Medusa.

Marx, Karl (1973). Grundrisse. Foundations of the Critique of Political Economy (Rough Draft). London: Penguin Books.

Marx, Karl (1976). Capital. A Critique of Political Economy. Volume I. London: Penguin Books.

McCulloch, J. y A. Ávila (2002). Viaje hacia el interior: el despacho de Ramón Gomez de la Serna, en Los ismos de Ramón Gómez de la Serna y un apéndice circense. Madrid: Sociedad Estatal para la Acción Cultural Exterior, pp. 355-392.

Navarro Domínguez, Eloy (2003). El intelectual adolescente: Ramón Gómez de la Serna (1905-1912). Madrid: Biblioteca Nueva.

Prieto, Antonio (2005). «Las cosas y la individualidad excéntrica de Gómez de la Serna», Dicenda: Cuadernos de Filología Hispánica. 23, pp. 181-193.

Rey Briones, Antonio del (1992). La novela de Ramón Gómez de la Serna. Madrid: Editorial Verbum.

Soldevila-Durante, Ignacio (1988). «Para la recuperación de una prehistoria embarazosa (una etapa marxista de Ramón Gómez de la Serna)», en Nigel Dennis (ed.), Studies on Ramón Gómez de la Serna. Ottawa: Dovehouse Editions Canada, pp. 23-43.

Terdiman, Richard (1993). Present Past: Modernity and the Memory Crisis. Ithaca: Cornell University Press.

Ugarte, Michael (1996). Madrid 1900. The Capital as Cradle of Literature and Culture. Pennsylvania: The Pennsylvania State University Press.

Ury, John (1995). «The consumption of tourism», en Consuming Places. London and New York: Routledge, pp. 129-140.

Valis, Noël (2002). The Culture of Cursilería. Bad Taste, Kitsch and Class in Modern Spain. Durham and London: Duke University Press. 